\title{
Prognostic factors that affect the survival of gastric cancer
}

\author{
Mide kanserinde săğkalımı etkileyen prognostik faktörler
}

\author{
Birsen Yücel*, Saadettin Kılıçkap, Yıllar Lehimcioğlu Okur, Eda Erdiş, Ebru \\ Atasever Akkaş, Mine Şalk
}

Department of Radiation Oncology (Assist. Prof. B. Yücel, MD, Assoc. Prof. S. Kılıçkap, MD, Assist. Prof. Y. L. Okur, MD, E. Atasever, MD), Cumhuriyet University School of Medicine, TR58140 Sivas, Department of Radiation Oncology (E. Erdiş, MD), Antakya State Hospital, TR65143 Antakya, Department of Radiation Oncology (M. Şalk, MD), Urfa State Hospital, TR98765 Şanlıurfa

\begin{abstract}
Aims. The purpose of this study is to review the factors that affect the survival and clinicopathological characteristics of gastric cancer cases monitored and treated at our centre. Method. 112 gastric cancer patients who admitted to the Radiation Oncology Department of Cumhuriyet University Medical Faculty Research and Application Hospital between 2006 and 2010 were included in the study. The demographic, clinical, and histopathology data of the patients were obtained from the patient files and the hospital records. Results. This study analysed data of 112 patients of whom $90(80 \%)$ were men, and $22(20 \%)$ were women. The factors that determined survival were stage of the cancer, $\mathrm{T}$ and $\mathrm{N}$ stages, high grade, performance status, presence of anemia and hypoalbuminemia, presence of metastasis, extravascular invasion, weight loss, metastatic lymph node ratio $(>50 \%)$ and a high level of serum CEA and CA19-9. The stage, performance status, anemia at the time of diagnosis were determined as independent prognostic factors that affect survival after performing multivariate analysis. Conclusion. Many studies have defined numerous prognostic factors for gastric cancer. In concordance with the literature, this study sets forth that the most important factors in terms of prognosis are the stage, the performance status, and the presence of anemia at diagnosis the time of diagnosis.
\end{abstract}

Keywords: Gastric cancer, prognosis, anemia, stage, performance status

\section{Özet}

Amaç. $\mathrm{Bu}$ çalışmanın amacı, kliniğimizde takip ve tedavi edilen mide kanserli vakaların sağkalımını etkileyen faktörleri ve klinikopatolojik özellikleri gözden geçirmektir. Yöntem. 20062010 yılları arasında Cumhuriyet Üniversitesi Tıp Fakültesi Araştırma ve Uygulama Hastanesi Radyasyon Onkolojisi Bölümüne başvuran 112 mide kanserli hasta bu çalışmaya dahil edildi. Hastaların demografik, klinik ve histopatolojik verileri hasta dosyaları ve hastane kayıtlarından elde edildi. Bulgular. Bu çalışmada, 90'1 (\%80) erkek ve 22'si (\%20) kadın 112 hastanın verisi analiz edildi. Kanserin evresi, $\mathrm{T}$ ve $\mathrm{N}$ evresi, yüksek grade, performans durumu, anemi ve hipoalbuminemi varlığı, metastaz varlığı, ekstravasküler invazyon, kilo kaybı, metastatik lenf nodu oranı (>\%50), yüksek CEA ve CA19-9 seviyesi sağkalımı belirleyen faktörlerdi. Çok değişkenli analizde, evre, performans durumu, tanı anında aneminin olması sağkalımı bağımsız olarak etkileyen prognostik faktörlerdi. Sonuç. Mide kanseri için birçok prognostik faktör tanımlamıştır. Bu çalışmada literatürle uyumlu olarak, evre, performans durumu ve tanıda aneminin varlığı en önemli prognostik faktörlerdi.

Anahtar sözcükler: Gastrik kanser, prognoz, anemi, evre, performans durumu

Geliş tarihi/Received: November 23, 2011; Kabul tarihi/Accepted: May 03, 2012

\section{*Corresponding author:}

Dr. Birsen Yücel, Radyasyon Onkolojisi Bilim Dalı, Cumhuriyet Üniversitesi Tıp Fakültesi, TR58140 Sivas. E-mail: yucelbirsen@yahoo.com 


\section{Introduction}

Gastric cancer is an important health issue as it is diagnosed at an advanced stage, and it is aggressive even after curative surgery. Gastric cancer is responsible for approximately 934.000 new cases annually (8.6\% of new cancer cases). Almost two thirds of cases occur in Eastern Europe, South America, and Asia [1]. Moreover, it is responsible for approximately 700.349 deaths worldwide annually and the case-fatality ratio of gastric cancer is higher in comparison to more common types of cancer (gastric cancer 0.75, Colon cancer 0.52, breast cancer 0.36, prostate cancer 0.33) [1]. The male/female ratio is approximately 1.5/1 [2]. Gastric cancer incidences change according to localization; cardia-originated tumors are five times higher in men [3]. Incidence of gastric cancer is observed more in black people, people with a low socio-economic background, and in developing countries [4]. Complete resection (R0) of the tumor can only be achieved with curative treatment for this illness; however, the extent of lymph node dissection is controversial (D1-D2 dissection) [5, 6]. A major problem in gastric cancer treatment is local recurrence. Local recurrence is observed in 50\% of patients after surgery, and 52\%$68 \%$ in autopsy series[7]. For patients that only undergo surgery the 5-year survival rate decreases by $50 \%$ for $\mathrm{T} 2$ patients, $45 \%$ for $\mathrm{T} 3$ patients, and $15 \%$ for $\mathrm{T} 4$ patients; for patients with lymph node involvement the survival rate decreases $20 \%$ for $\mathrm{N} 1$ patients, and $10 \%$ for $\mathrm{N} 2$ patients [7]. The most important prognostic factors are lymph node metastasis and the depth of the tumor. The prognosis of patients without lymph node involvement is better in comparison to patients that have lymph node involvement. Lymph node metastasis is positively correlated with the depth of the tumor. After curative surgery, serosal invasion and lymphovascular invasion are important prognostic factors for patients with negative lymph node involvement [8-12]. CEA and CA19-9 level increase by $30 \%-40 \%$ in primary stomach neoplasms; however, these high-level antigens generally occur in advanced stage [13,14].

We aimed to determine the factors that affect the survival of our registered gastric cancer patients in the light of the current literature.

\section{Material and method}

The demographic, clinical, and histopathological data of gastric cancer patients registered at the Radiation Oncology Department of Cumhuriyet University Medical Faculty Research and Application Hospital between 2006 and 2010 were obtained from patient files and hospital records. The current state of patients that had not come to the follow-up visits in the last three months was obtained by calling them in order to form their survival analysis. The patient's performance status was evaluated according to the ECOG (Eastern Cooperative Oncology Group) scoring system at the time of their registration. Patients with a haemoglobin level below $12 \mathrm{~g} / \mathrm{dL}$ for anemia and albumin level below $3.2 \mathrm{~g} / \mathrm{dL}$ for hypoalbuminemia, and a weight loss exceeding $10 \%$ of their weight monthly were included in this study. The stage of patients was determined according to the 2002 UICC/AJCC TNM classification. Patients without sufficient data were eliminated from the study. The Chi-Square test, the Mann-Whitney U test, and Kaplan-Meier analysis were used for analyses. Multivariate analysis (Cox regression analysis) was used to assess the independent factors that have an effect on survival. P values $\leq 0.05$ were considered as statistically significant throughout the study.

The Ethical Committee of Cumhuriyet University Faculty of Medicine approved this study in concordance with the declaration of Helsinki.

\section{Results}

This study analysed data belonging to 112 patients; 90 (80\%) men, and $22(20 \%)$ women. The median age of the patients was 62 (min-max=31-85). The median age for both genders was similar (Men=60, Women $=58 ; \mathrm{p}=0.284)$. Twenty-five $(22 \%)$ patients had a history of cancer in the family, $52(46 \%)$ had a history of smoking, and $31(28 \%)$ had a disease that caused co-morbidity such as diabetes mellitus and hypertension. The 
performance status of patients were assessed at registration; $60(54 \%)$ patients were identified as ECOG0, 38 (34\%) patients were identified as ECOG1, and $14(12 \%)$ patients were identified as being above ECOG1Fifty seven (51\%) patients had a haemoglobin level below $12 \mathrm{~g} / \mathrm{dL}$, and 37 (34\%) patients had an albumin level below 3.2 $\mathrm{g} / \mathrm{dL}$. A high preoperative CEA level was observed in 25 (29\%) patients, and a high preoperative CA19-9 level was observed in $22(25 \%)$ patients. Regarding tumor site, 21 (19\%) tumors were localized in the proximal part of the stomach (gastroesophageal junction, fundus and cardia) and $91(81 \%)$ tumors were localized in the distal part of the stomach (corpus, antrum and plyrous). Forthy nine (45\%) patients were diagnosed in the early stage, whereas $63(55 \%)$ patients were diagnosed in the advanced stage. According to the histopathological diagnosis, the most frequent type of pathology was adenocarcinoma; observed in 107 (95\%) patients. The majority of patients were Grade III; 41 (47\%) patients. Perineural and vascular invasion was not identified in pathology reports of patients diagnosed in the advanced stage who unable to undergo curative surgery. Perineural invasion was seen in $46(60 \%)$ of patients in which perineural and lymphovascular invasion was detected, while lymphovascular invasion was seen in 52 (67\%) patients. Advanced staged patients generally underwent only biopsy; 24 (\%22) patients, $48(43 \%)$ patients underwent a total gastrectomy, $39(35 \%)$ underwent a subtotal gastrectomy. The lymph node dissection type of patients that underwent surgery at other centres could not be completely identified because they admitted to our clinic after surgery was performed at another health center, and they lacked surgical epicrisis. But most patients had undergone adequate lymph node dissection. The median tumor size was $5 \mathrm{~cm}$, the median number of examined lymph nodes was 19 , and the median number of involved lymph nodes was 5. Six (5\%) patients had been treated only with surgery 20 $(18 \%)$ patients with surgery + chemotherapy, $62(55 \%)$ patients with surgery + chemoradiotherapy, $17(15 \%)$ advanced stage patients with chemotherapy, 2 (2\%) patients only with radiotherapy, and $5(5 \%)$ patients with palliative treatment. Table 1 illustrates the demographic characteristics of the patients. Twenty eight (68\%) advanced stage patients had a Grade III, $37(67 \%)$ patients had anemia, $26(56 \%)$ patients had perineural invasion, $27(52 \%)$ patients had lymphovascular invasion, $18(75 \%)$ patients had a high CEA level, 18 (82\%) had a high CA19-9 level, 27 (82\%) had extravascular invasion, $23(85 \%)$ patients had metastatic lymph nodes ratio $(>50 \%)$, and $35(68 \%)$ patients had a performance status above ECOG 0. All of these characteristics were statistically significant in the advanced stage. Table 2 illustrates $p$ values of characteristics in the early and advanced stages. The median follow-up was 18 months (164 months); the median survival for all stages was 28 months, and 2-year survival was $53 \%$. A median survival time could not be obtained for Stage I and Stage II patients; the 2 -year survival was $90 \%$ for Stage I patients, and $76 \%$ for Stage II patients. The median survival was 22.2 months for Stage III patients, and 12.4 months for Stage IV patients; the 2-year survival was $37 \%$ for Stage III patients, and $20 \%$ for Stage IV patients. According to the univariate analysis, stage, $\mathrm{T}$ and $\mathrm{N}$ stages, metastatic lymph node ratio (involved lymph node/examined lymph node), weight loss, performance status, anemia, hypoalbuminemia, grade, CEA, CA19-9, extravascular invasion, metastasis at time of the diagnosis, and metastasis developed during follow-up were determined as factors that have an effect on survival. Perineural and lymphovascular invasion, tumor size and site have no statistical significant by univariate analysis. Table 3 illustrates factors that have an effect on survival. According to the multivariate analysis, early and advanced stage, the patient's performance status, and anemia at the time of the diagnosis were determined as independent prognostic factors that have an effect on survival. Table 4 illustrates multivariate analysis results. Local recurrence was seen in $3(3 \%)$ patients, while distant metastasis developed in 17 (18\%) patients. Distant metastasis was seen in the liver of 13 (76\%) patients; the lungs, bones, the supra region of neck and the intraabdominal were the other regions where metastasis developed. 
Table 1. Demographic characteristics of gastric cancer patients.

\begin{tabular}{|c|c|c|c|}
\hline & & $\mathbf{n}$ & $\%$ \\
\hline \multirow[t]{2}{*}{ Gender } & Male & 22 & 20 \\
\hline & Female & 90 & 80 \\
\hline Family Cancer history & Yes & 25 & 22 \\
\hline Smoking & Yes & 52 & 46 \\
\hline Co-morbidity & Yes & 31 & 28 \\
\hline \multirow[t]{3}{*}{ ECOG PS } & 0 & 60 & 54 \\
\hline & 1 & 38 & 34 \\
\hline & $>1$ & 14 & 12 \\
\hline Anemia & $\mathrm{Hgb}<12 \mathrm{~g} / \mathrm{dL}$ & 57 & 51 \\
\hline Hypoalbuminemia & $\mathrm{Alb}<3.2 \mathrm{~g} / \mathrm{dL}$ & 37 & 34 \\
\hline CEA & High & 25 & 29 \\
\hline CA19-9 & High & 22 & 25 \\
\hline \multirow[t]{4}{*}{ Histopathology } & Adenocarcinoma & 88 & 78 \\
\hline & Signet ring cells & 19 & 17 \\
\hline & Neuroendocrine & 4 & 4 \\
\hline & Sarcomatoid carcinoma & 1 & 1 \\
\hline \multirow[t]{4}{*}{ Tumor site } & Gastroesophageal junction & 2 & 2 \\
\hline & Fundus, cardia & 19 & 17 \\
\hline & Corpus & 53 & 47 \\
\hline & Antrum, pylorus & 38 & 34 \\
\hline \multirow[t]{3}{*}{ Surgery Type } & Subtotal gastrectomy & 39 & 35 \\
\hline & Total gastrectomy & 48 & 43 \\
\hline & Biopsy & 24 & 22 \\
\hline \multirow[t]{4}{*}{ Stage } & $\mathrm{I}$ & 12 & 11 \\
\hline & II & 37 & 34 \\
\hline & III & 44 & 40 \\
\hline & IV & 19 & 15 \\
\hline \multirow[t]{3}{*}{ Grade } & I & 14 & 16 \\
\hline & II & 32 & 37 \\
\hline & III & 41 & 47 \\
\hline Perineural Invasion & + & 46 & 60 \\
\hline Lymphovascular Invasion & + & 52 & 67 \\
\hline Tumor size & \multicolumn{3}{|l|}{ Median size: $5(1-15 \mathrm{~cm})$} \\
\hline Number of examined lymph nodes & \multicolumn{3}{|c|}{ Median number of examined lymph nodes : $19(2-41)$} \\
\hline Number of involved lymph nodes & \multicolumn{3}{|c|}{ Median number of involved lymph nodes: $5(0-30)$} \\
\hline \multirow[t]{3}{*}{ Treatment } & Surgery & 88 & 79 \\
\hline & Chemotherapy & 101 & 90 \\
\hline & Radiotherapy & 64 & 57 \\
\hline
\end{tabular}

\section{Discussion}

Even though numerous studies have successfully indentified prognostic factors for gastric carcinoma, treatment is still not at the desired level due to the aggressive progress of the tumor. Studies in literature have shown two important prognostic factors as the degree of penetration of the tumor through the gastric wall and the presence of lymph node involvement. Gunji et al. [15] demonstrated that gastric cancer patients with four and more positive lymph nodes were likely to suffer recurrence and had a shorter survival. Okajima [16] indicated that the anatomic distribution of a metastatic lymph node had prognostic importance. Marchet et al. [17] conducted D1, D2, and D3 dissections on 1853 gastric cancer patients; they identified that the metastatic lymph node ratio was the most important prognostic factor, regardless of the dissection type and number of metastatic lymph nodes. 
Table 2. Characteristics of early and advanced stage patients.

\begin{tabular}{lllll}
\hline & & Stage I-II Stage III-IV & p \\
& & $\mathbf{n}(\boldsymbol{\%})$ & $\mathbf{n}(\boldsymbol{\%})$ & \\
\hline Grade & I & $9(64)$ & $5(36)$ & 0.004 \\
& II & $22(69)$ & $10(31)$ & \\
\hline III & $13(32)$ & $28(68)$ & \\
\hline Perineural Invasion & No & $31(56)$ & $24(44)$ & 0.01 \\
& Yes & $18(33)$ & $37(67)$ & \\
\hline Extracapsular Invasion & No & $21(70)$ & $9(30)$ & 0.02 \\
& No & $20(44)$ & $26(56)$ & \\
\hline Hypoalbuminemia & Yes & $6(18)$ & $27(82)$ & \\
& No & $35(48)$ & $38(52)$ & 0.167 \\
\hline Lymphovascular Invasion & No & $13(36)$ & $23(64)$ & \\
& Yes & $25(46)$ & $8(33)$ & 0.209 \\
\hline CEA & Normal & $31(51)$ & $30(49)$ & 0.026 \\
& High & $6(25)$ & $18(75)$ & \\
\hline CA19-9 & Normal & $33(51)$ & $32(49)$ & 0.006 \\
& High & $4(18)$ & $18(82)$ & \\
\hline ECOG PS & ECOG0 & $33(56)$ & $26(44)$ & 0.008 \\
\hline Lymph node ratio & ECOG>0 & $16(32)$ & $35(68)$ & \\
\hline Localization & $<\% 50$ & $44(72)$ & $17(28)$ & $<0.001$ \\
& $\geq \% 50$ & $4(15)$ & $23(85)$ & \\
\hline
\end{tabular}

Researchers divided patients into two groups based on their examined number of lymph nodes; Group 1 consisted of 1421 patients with more than 15 lymph nodes and group II consisted of 432 patients with 15 or less lymph nodes. In conclusion of univariate analysis, age (>70), tumor site, surgery type, grade, T stage, the anatomical location and number of the metatstatic lymph nodes were deemed important prognostic factors in Group I, while important prognostic factors in Group II were gender, age, tumor site, surgery type, $\mathrm{T}$ stage, and the anatomical location and number of the metastatic lymph nodes. According to 2002 UICC/AJCC TNM classifications, the appropriate amount of lymph nodes to be removed during gastric cancer staging is 15 and more lymph nodes [18]. In this study, the median number of examined lymph nodes was 19 (2-41). The twoyear survival rate was $86 \%$ for N0 patients, $73 \%$ for N1 (1-6 involved lymph nodes), $45 \%$ for $\mathrm{N} 2$ (7-15) patients, 35\% for N3 (16 and over) patients, and 6\% for Nx patients; in conclusion of univariate analysis the nodal stage had an effect on survival. The two-year survival rate for Nx patients is low as Nx patients are generally in Stage IV. Additionally, prognosis of patients with extravascular invasion in metastatic lymph nodes affected more adversely. In their study, conducted on 1654 patients that had undergone a curative gastrectomy, Siewert et al. [8] identified that metastatic lymph nodes ratio ( $<\% 20$ and $>\% 20$ ) and the presence of residual disease were two important independent prognostic factors during their 10-year analysis. They determined that the development of postoperative complications, $\mathrm{N}$ stage, depth of wall invasion, presence of distant metastasis, tumor size were associated with prognosis. Numerous studies have proven that metastatic lymph nodes ratio is an important prognostic factor; these studies also investigate the prognostic importance of different ratios [8, 17]. In our study, we accepted this ratio as $50 \%$. A lymph node ratio above and below $50 \%$ had an effect on survival according to univariate analysis. The two-year survival for patients with a lymph node ratio below $50 \%$ was $77 \%$, and the two-year survival for patients with a lymph node ratio above $50 \%$ was $34 \%$. 
Table 3. Prognostic factors that affect survival according to univariate analysis.

\begin{tabular}{|c|c|c|c|}
\hline Univariate Analysis & & 2 year survival $(\%)$ & $\mathbf{p}$ \\
\hline Stage & $\mathrm{I}$ & 90 & $<0.001$ \\
\hline & II & 76 & \\
\hline & III & 37 & \\
\hline & IV & 20 & \\
\hline Grade & I & 84 & 0.009 \\
\hline & II & 66 & \\
\hline & III & 49 & \\
\hline Perineural Invasion & No & 65 & 0.489 \\
\hline & Yes & 60 & \\
\hline Lymphovascular Invasion & No & 76 & 0.079 \\
\hline & Yes & 55 & \\
\hline Tumor size & $<5 \mathrm{~cm}$ & 67 & 0.187 \\
\hline & $>5 \mathrm{~cm}$ & 57 & \\
\hline Lymph node stage & 0 & 86 & $<0.001$ \\
\hline & $\mathrm{I}$ & 73 & \\
\hline & II & 45 & \\
\hline & III & 35 & \\
\hline Metastasis at Diagnosis & No & 57 & 0.019 \\
\hline & Yes & 25 & \\
\hline Anemia & No & 74 & 0.001 \\
\hline & Yes & 31 & \\
\hline Hypoalbuminemia & No & 67 & $<0.001$ \\
\hline & Yes & 26 & \\
\hline Performance status & ECOG0 & 72 & $<0.001$ \\
\hline & $\mathrm{ECOG}>0$ & 34 & \\
\hline CEA & Normal & 63 & $<0.001$ \\
\hline & High & 31 & \\
\hline CA19-9 & Normal & 61 & $<0.001$ \\
\hline & High & 29 & \\
\hline T stage & I & 83 & $<0.001$ \\
\hline & II & 87 & \\
\hline & III & 60 & \\
\hline & IV & 26 & \\
\hline Weight Loss & No & 61 & 0.009 \\
\hline & Yes & 38 & \\
\hline Lymph node ratio & $<\% 50$ & 77 & $<0.001$ \\
\hline & $>\% 50$ & 34 & \\
\hline Tumor site & Proximal & 64 & 0.497 \\
\hline & Distal & 50 & \\
\hline Metastasis & No & 59 & 0.002 \\
\hline & Yes & 20 & \\
\hline Extravascular Invasion & No & 73 & 0.014 \\
\hline & Yes & 52 & \\
\hline Age & $<65$ & 60 & 0.029 \\
\hline & $>65$ & 40 & \\
\hline
\end{tabular}

Table 4. Independent prognostic factors for multivariate analysis.

\begin{tabular}{lllll}
\hline Multivariate Analysis & $\operatorname{Exp}(\mathbf{B})$ & \%95 confidence interval & p \\
\hline $\begin{array}{l}\text { Stage } \\
\text { Performance status }\end{array}$ & I-II and III-IV & 2,75 & $1,18-6,44$ & 0,019 \\
& ECOG0 & 2,92 & $1,34-6,36$ & 0,007 \\
Anemia at Diagnosis & $\begin{array}{l}\text { No } \\
\text { Yes }\end{array}$ & 2,06 & $1,02-4,16$ & 0,043 \\
& & & \\
\hline
\end{tabular}


Dockerty [19] reported that the 5-year survival was $100 \%$ for tumor invasion just to the mucous membrane, $61 \%$ for tumors passing through the mucous membrane, $44 \%$ for tumors invading the entire stomach wall, and $15 \%$ for tumors with nodal distribution. The British Study Group analysed the tumor site, gross appearance of the tumor, the number of involved lymph nodes, depth of tumor invasion, the nodal stage, and the tumor grade, and concluded that depth of tumor invasion, lymph node involvement, and positive surgery borders were prognostic factors [20]. According to the univariate analysis of our patients, the increased depth of tumor invasion has an adverse effect on survival. The two-year survival rate was $83 \%$ in T1 tumor, $87 \%$ in T2 tumor, $60 \%$ in T3 tumor, and $26 \%$ in $\mathrm{T} 4$ tumor.Saito et al. [21] stated that the size of the tumor was related to lymphovascular invasion, lymph node metastasis, depth of wall invasion, and differentiation. According to the multivariate analysis, depth of wall invasion, lymph node metastasis, lymphovascular invasion, the size of the tumor were also defined as independent prognostic factors. In conclusion of analyses, prognosis for a tumor size $<8 \mathrm{~cm}$ was better than a tumor size $>8 \mathrm{~cm}$. However, the adverse prognostic factor of the tumor size is controversial $[22,23]$. Due to the fact that the median tumor size was $5 \mathrm{~cm}$, the statistical analysis of the tumor size in our study was done based on this value. When patients were analysed between $\leq 5 \mathrm{~cm}$ and $>5 \mathrm{~cm}$, the tumor size did not have an effect on survival. Whereas the two-year survival was $67 \%$ for a tumor size $\leq 5 \mathrm{~cm}$ and $57 \%$ for a tumor size $>5 \mathrm{~cm}$. However, $\mathrm{T}$ and $\mathrm{N}$ stages were factors that had an effect on survival according to the univariate analysis; the stages (I-II and III-IV) were independent prognostic factors according to the multivariate analysis. Prognosis was affected adversely by lymphatic, venous, and perineural invasion [24, 25]. Lee et al. [26] analysed 304 patients without lymph node involvement. They demonstrated that lymphovascular invasion and depth of wall invasion were independent prognostic factors for survival. In our study, prognosis was not significantly related to perineural and lymphovascular invasions, even though patients with perineural and lymphovascular invasions were generally in advanced stages. In general, high grade and diffuse-type carcinoma, seen in advanced stages, are adverse prognostic factors. Gross tumoral appearance as described by Borrmann has been shown to have prognostic significance in several large studies. These studies concluded that Borrmann type I and type II (polypoid and ulcerating) cancers seem to have a better prognosis than Borrmann type III and IV (infiltrating cancers and linitis plastica) cancers [27, 28]. But other studies did not confirm this result. While the location of the tumor carries independent prognostic importance, proximal tumors (cardia, gastroesophageal junction) are tumors that display more aggressive behaviour [24]. In our study, analysis was only conducted on proximal and distal localization due to the lack of linitis plastica cases. However, it was determined that tumor localization had no effect on the prognosis of our patients. We believe that this is due to the limited number of patients with proximal tumors. In addition, our study proves that high grade patients are usually in the advanced stages and have a worse prognosis, as stated in literature. Men have a worse prognosis than women, because their tumors are localized generally in cardia [29]. In our study, a statistically significant relationship was not identified between gender and prognosis. Kodera et al. [30] identified a \%17 preoperative elevated CEA level and a \%16 preoperative elevated CA19-9 level in 663 gastric cancer patients. According to the multivariate analysis of this study, the prognostic importance of CA19-9 was higher in comparison to the prognostic importance of CEA. In our study, $29 \%$ of patients had a high CEA level, and 25\% of patients had a high CA19-9 level. A high preoperative CEA level had an adverse effect on the prognosis of patients, regardless of all other major prognostic factors being good [31-33]. According to the univariate analysis in our study, a high levels of CEA and CA19-9 had an adverse effect on prognosis. Investigations to date have demonstrated that inflammation-based factors such as elevated serum CRP levels (C-reactive protein), and hypoalbuminemia could be markers to predict malignant potential of the tumor or worse prognosis of patients with gastrointestinal tumors [34-36]. Anemia, high grade, a high level of CEA and CA19-9, perineural invasion, and a bad performance status were seen more in advanced stage 
patients. According to the univariate analysis, anemia, hypoalbuminemia, performance status, and weight loss had an effect on prognosis. According to the multivariate analysis conducted on gastric cancer patients, Maehara et al. [37] identified 10 prognostic factors; depth of wall invasion, lymph node involvement, lymph node dissection, tumor size, liver metastasis, peritoneal dissemination, lymphatic invasion, and vascular invasion, lesions in the whole stomach, and lesions in the middle of the stomach were independent prognostic factors. According to the multivariate analysis conducted in our study, the independent prognostic factors were stage, anemia at the time of the diagnosis, and the performance status of the patients. Anemia at the time of the diagnosis made prognosis 2.06 times worse, the performance status made prognosis 2.92 times worse, and the stage made prognosis 2.75 times worse.

In concordance with the literature, our study proves that stage, performance status, and anemia at the time of the diagnosis are the most important prognostic factors that define survival. Identifying prognostic factors of gastric cancer before hand sheds light for clinicians when planning the process and treatment of the illness. We believe that conducting future multi-center studies will be a better approach to increase the number of cases analysed.

\section{References}

1. Parkin DM, Bray F, Ferlay J, Pisani P. Global cancer statistics, 2002. CA Cancer J Clin 2005; 55: 74-108.

2. Ferlay J, Bray F, Pisani P. Parkin DM. Globocan 2002 cancer incidence, mortality and prevalence worldwide. IARC cancerbase no. 5, version 2.0 Lyon: IARC Press; 2004.

3. El-Serag HB, Mason AC, Petersen N, Key CR. Epidemiological differences between adenocarcinoma of the oesophagus and adenocarcinoma of the gastric cardia in the USA. Gut 2002; 50: 368-72.

4. Parkin DM, Whelan SL, Ferlay J, Raymond L, Young J. Cancer incidence in five continents, vol VII. Lyon: IARC Scientific Publications, 1997: 822-3.

5. Roviello F, Marrelli D, Morgagni P, de Manzoni G, Di Leo A, Vindigni C, Saragoni L, Tomezzoli A, Kurihara H; Italian Research Group for Gastric Cancer. Survival benefit of extended D2 lymphadenectomy in gastric cancer with involvement of second level lymph nodes: a longitudinal multicenter study.Ann Surg Oncol 2002; 9: 894-900.

6. Hochwald SN, Kim S, Klimstra DS, Brennan MF, Karpeh MS. Analysis of 154 actual five-year survivors of gastric cancer. J Gastrointest Surg 2000; 4: 520.

7. Gunderson LL. Gastric cancer--patterns of relapse after surgical resection. Semin Radiat Oncol 2002; 12: 150-61.

8. Siewert JR, Böttcher K, Stein HJ, Roder JD. Relevant prognostic factors in gastric cancer: ten-year results of the German Gastric Cancer Study. Ann Surg 1998; 228: 449-61.

9. Wu CW, Hsieh MC, Lo SS, Tsay SH, Li AF, Lui WY, P'eng FK. Prognostic indicators for survival after curative resection for patients with carcinoma of the stomach. Dig Dis Sci 1997; 42: 1265-9.

10. Wu CW, Hsieh MC, Lo SS, Tsay SH, Lui WY, P'eng FK. Relation of number of positive lymph nodes to the prognosis of patients with primary gastric adenocarcinoma. Gut 1996; 38: 525-7.

11. Hyung WJ, Lee JH, Choi SH, Min JS, Noh SH. Prognostic impact of lymphatic and/or blood vessel invasion in patients with node-negative advanced gastric cancer. Ann Surg Oncol 2002; 9: 562-7.

12. Kooby DA, Suriawinata A, Klimstra DS, Brennan MF, Karpeh MS. Biologic predictors of survival in node-negative gastric cancer. Ann Surg 2003; 237: 82835.

13. Hakama M, Stenman UH, Knekt P, Järvisalo J, Leino A, Hakulinen T, Maatela J, 
Aromaa A. Tumour markers and screening for gastrointestinal cancer: a follow up study in Finland. J Med Screen 1994; 1: 60-4.

14. Pectasides D, Mylonakis A, Kostopoulou M, Papadopoulou M, Triantafillis D, Varthalitis J, Dimitriades M, Athanassiou A. CEA, CA 19-9, and CA-50 in monitoring gastric carcinoma. Am J Clin Oncol 1997; 20: 348-53.

15. Gunji Y, Suzuki T, Hori S, Hayashi H, Matsubara H, Shimada H, Ochiai T. Prognostic significance of the number of metastatic lymph nodes in early gastric cancer. Dig Surg 2003; 20: 148.

16. Okajima K. Prognostic factors of gastric cancer patients a study by univariate analysis (in Japanese, with English abstract). Jpn J Gastroenterol Surg 1997; 30: 700-11.

17. Marchet A, Mocellin S, Ambrosi A, de Manzoni G, Di Leo A, Marrelli D, Roviello F, Morgagni P, Saragoni L, Natalini G, De Santis F, Baiocchi L, Coniglio A, Nitti D; Italian Research Group for Gastric Cancer Study (GIRCG). The prognostic value of N-ratio in patients with gastric cancer. Eur J Surg Oncol 2008; 34: 159-65.

18. Sobin LH, Witekind CN. TNM classification of malignant tumors. International Union Cancer. 6th ed. New York: John Wiley \& Sons; 2002.

19. Dockerty MB: Pathology aspects of primary malignant neoplasms of stomach. In ReMine WH, Priestly JT, Berkson J (eds): Cancer os the Stomach. Phladelphia, WB Saunders, 1964; pp: 173.

20. Yu CC, Levison DA, Dunn JA, Ward LC, Demonakou M, Allum WH, Hallisey MT. Pathological prognostic factors in the second British Stomach Cancer Group trial of adjuvant therapy in resectable gastric cancer. Br J Cancer 1995; 71: 110610.

21. Saito H, Osaki T, Murakami D, Sakamoto T, Kanaji S, Oro S, Tatebe S, Tsujitani $\mathrm{S}$, Ikeguchi $\mathrm{M}$. Macroscopic tumor size as a simple prognostic indicator in patients with gastric cancer. Am J of Surg 2006; 192: 296-300.

22. Wang X, Wan F, Pan J, Yu GZ, Chen Y, Wang JJ. Tumor size: a non-neglectable independent prognostic factor for gastric cancer. J Surg Oncol 2008; 97: 236-40.

23. Shiraishi N, Sato K, Yasuda K, Inomata M, Kitano S. Multivariate prognostic study on large gastric cancer. J Surg Oncol 2007; 96: 14-8.

24. Van Krieken JHJM, Sasako M, Van de Vele CJH. Gastric cancer. In: Gospodarowicz MK, Henson DE, Hutter RVP, O'Sullivan B, Sobin LH, Wittekind C, eds. Prognostic Factors in Cancer. New York: Wiley-Liss; 2001:251-265.

25. Bunt AM, Hogendoorn PC, van de Velde CJ, Bruijn JA, Hermans J. Lymph node staging standards in gastric cancer. J Clin Oncol 1995; 13: 2309-16.

26. Lee CC, Wu CW, Lo SS, Chen JH, Li AF, Hsieh MC, Shen KH, Lui WY. Survival predictors in patients with node-negative gastric carcinoma. J Gastroenterol Hepatol 2007; 22: 1014-8.

27. Dent DM, Werner ID, Novis B, Cheverton P, Brice P. Prospective randomized trial of combined oncological therapy for gastric carcinoma. Cancer 1979; 44: 385.

28. Tsukiyama I, Akine Y, Kajiura Y, Ogino T, Yamashita K, Egawa S, Hijikata J, Kitagawa T. Radiation therapy for advanced gastric cancer. Int J Radiat Oncol Biol Phys 1988; 15: 123.

29. Maguire A, Porta M, Sanz-Anquela JM, Ruano I, Malats N, Piñol JL. Sex as a prognostic factor in gastric cancer. Eur J Cancer 1996; 32A: 1303-9.

30. Kodera Y, Yamamura Y, Torii A, Uesaka K, Hirai T, Yasui K, Morimoto T, Kato T, Kito T. The prognostiv value of preoperatif serum levels of CEA and Ca19, 9 inpatient with gastric cancer: Am J Gastroenterol 1996; 91: 149-53.

31. Nakane Y, Okamura S, Akehira K, Boku T, Okusa T, Tanaka K, Hioki K. Correlation of preoperative carcinoembryonic antigen levels and prognosis of gastric cancer patients. Cancer 1994; 73: 2703-8. 
32. Sakamoto J, Nakazato H, Teramukai S, Ohashi Y, Takahashi Y, Mai M, Toge T, Okura H, Kodaira S, Maetani S, Okajima K, Nomoto K, Hattori T, Inokuchi K. Association between preoperative plasma CEA levels and the prognosis of gastric cancer following curative resection. Tumor Marker Committee, Japanese Foundation for Multidisciplinary Treatment of Cancer, Tokyo, Japan. Surg Oncol 1996; 5: 133-9.

33. Maehara Y, Kusumoto T, Takahashi I, Kakeji Y, Baba H, Akazawa K, Sugimachi K. Predictive value of preoperative carcinoembryonic antigen levels for the prognosis of patients with well-differentiated gastric cancer. A multivariate analysis. A multivariate analysis. Oncology 1994; 51: 234-7.

34. Nozoe T, Mori E, Takahashi I, Ezaki T. Preoperative elevation of serum Creactive protein as an independent prognostic indicator of colorectal carcinoma. Surg Today 2008; 38: 597-602.

35. Lien YC, Hsieh CC, Wu YC, Hsu HS, Hsu WH, Wang LS, Huang MH, Huang BS. Preoperative serum albumin level is a prognostic indicator for adenocarcinoma of the gastric cardia. J Gastrointest Surg 2004; 8: 1041-8.

36. Oñate-Ocaña LF, Aiello-Crocifoglio V, Gallardo-Rincón D, Herrera-Goepfert R, Brom-Valladares R, Carrillo JF, Cervera E, Mohar-Betancourt A. Serum albumin as a significant prognostic factor for patients with gastric carcinoma. Ann Surg Oncol 2007; 14: 381-9.

37. Maehara Y, Kakeji Y, Oda S, Takahashi I, Akazawa K, Sugimachi K. Time trends of surgical treatment and the prognosis for Japanese patients with gastric cancer. Br J Cancer 2000; 83: 986-91. 